\title{
STUDI EVALUATIF TENTANG IMPLEMENTASI PROGRAM PRAKTIK KERJA INDUSTRI (PRAKERIN) DI PROGRAM STUDI KEAHLIAN AGRIBISNIS PRODUKSI TANAMAN SMKN 1 PETANG
}

\author{
Oleh \\ N. P. S. Suantari, N. Natajaya, N. Yudana \\ Program Studi Administrasi Pendidikan, Program Pascasarjana \\ Universitas Pendidikan Ganesha \\ Singaraja. Indonesia \\ e-mail: \{ siti.suantari1,nyoman.natajaya,made.yudana\}@pasca.undiksha.ac.id
}

\begin{abstract}
Abstrak
Studi evaluasi ini bertujuan untuk mengetahui efektivitas penerapan Program Praktik Kerja Industri (prakerin) di Program Studi Keahlian Agribisnis Produksi Tanaman SMK N 1 Petang. Penelitian ini menggunakan model Context, Input, Process and Product (CIPP). Responden dalam penelitian ini berjumlah 89 orang yang terdiri dari kepala sekolah, wakil kepala sekolah, guru, siswa di SMKN 1 Petang. Data penelitian dikumpulkan dengan kuesioner model skala Likert yang mencakup komponen konteks, masukan, proses dan produk. Data yang diperoleh dianalisis secara statistik dengan terlebih dahulu mengubah skor menjadi skor $t$ dan menentukan arahnya ke dalam kuadran Glickman. Temuan penelitian ini adalah; (1) dari segi konteks, penerapan Prakerin tergolong efektif, (2) dari segi masukan, penerapan prakerin tergolong efektif, (3) dari segi proses, penerapan prakerin tergolong efektif, dan (4) dari segi produk, penerapan prakerin tergolong efektif. Sehingga, berdasarkan kuadran Glickman (++++), penerapan Program Praktik Kerja Industri (prakerin) di Program Studi Keahlian Agribisnis Produksi Tanaman di SMKN 1 Petang berada dalam kategori efektif. Kendala utama yang masih dihadapi adalah masih kurangnya kerjasama pihak sekolah dengan pihak DU/DI baik dalam menyusun kurikulum, standar kompetensi lulusan yang diinginkan dan keterserapan siswa di dunia kerja.
\end{abstract}

Kata Kunci : prakerin, studi eveluatif

\begin{abstract}
This evaluative study aims at knowing the effectiveness of implementation of the job training in plant production agribusiness department of SMK N 1 Petang. This research uses Context, Input, Process and Product (CIPP) model. The respondents of this research were 89 persons consisting of headmaster, vice headmaster, teachers, and students. The data collected by using questionnaire with Likert scale covering context, input, process and product. The collected data were analyzed statistically by changing into t-score and determining their direction in Glickman Quadrant. This research discovers: (1) in term of context, the implementation of job training is categorized into effective, (2) in term of input, the implementation of job training is categorized into effective, (3) in term of process, the implementation of job training is categorized into effective, and (4) in term of product, the implementation of job training is categorized into effective. So, based on Glickman quadrant $(++++)$, the implementation of the job training in plant production agribusiness department of SMK N 1 Petang is categorized into effective. The main obstacles which is still faced is the less cooperation between school and companies in arranging curriculum, students' competency standard, and absorptivity of the students in working world.
\end{abstract}

Keywords: job training, evaluative study. 


\section{PENDAHULUAN}

Maju mundurnya suatu bangsa terletak dari sumber daya manusia yang dimiliki. Kualitas sumber daya manusia yang mumpuni tentu akan mempermudah bangsa tersebut mengolah sumber daya alam menjadi lebih bermanfaat dan berguna untuk masyarakat. tujuan dan visi pendidikan nasional tersebut, dapat ditelaah bahwa pendidikan adalah mengembangkan potensi yang dimiliki oleh peserta didik. Untuk itulah sistem pendidikan pun harus diarahkan untuk mampu mengembangkan potensi tersebut. Di Indonesia pun telah dikembangkan Sekolah Menengah Kejuruan untuk mengakomodir potensi yang dimiliki siswa.

Ada tiga langkah inovatif dan revolusioner yang dilakukan pemerintah untuk menaikan citra pamor SMK di masyarakat. Pertama dengan menambah jumlah SMK dan mengurangi jumlah SMA. Sebagai imbas dari pengembangan SMK oleh pemerintah maka pada 26 April 2006 didirikanlah SMK N 1 Petang dengan bidang keahlian "Agribisnis dan Agroteknologi". Sekolah ini terletak di tempat yang sangat representatif yaitu di Desa Pelaga, Kecamatan Petang, Kabupaten Badung. Daerah ini adalah sentra pertanian di Kabupaten Badung dengan keadaan georgrafis yang sangat mendukung didirikannya SMK agribisnis dan agroteknologi. Terdapat dua program studi keahlian, Agribisnis Produksi Tanaman dan Agribisnis Hasil Pertanian. Mengingat usia SMK N 1 Petang yang masih relatif muda (kurang dari 10 tahun) maka dirasakan sangat perlu untuk melakukan evaluasi terhadap pelaksanaan prakerin di sekolah ini. Dengan melakukan evaluasi maka gambaran umum dan detail tentang pelaksanaan Prakerin dapat diketahui oleh guru,sehingga akan menjadi masukan bagi sekolah untuk terus meningkatkan kualitas prakerin. Evaluasi akan mencakup empat komponen, yaitu: konteks (context), masukan (input), proses (process) dan produk (product). Dalam penelitian ini, model evaluasi CIPP (context, input, process dan product).

Penelitian ini berfokus pada efektivitas penerapan Prakerin yang dilaksanakan di SMK Negeri 1 Petang, dengan rincian rumusan masalahnya sebagai berikut:

1) Bagaimana efektivitas implementasi program praktik kerja industri di program studi keahlian agribisnis produksi tanaman SMK N 1 Petang ditinjau dari segi konteks?

2) Bagaimana efektivitas implementasi program praktik kerja industri di program studi keahlian agribisnis produksi tanaman SMK N 1 Petang ditinjau dari segi masukan?

3) Bagaimana efektivitas implementasi program praktik kerja industri di program studi keahlian agribisnis produksi tanaman SMK N 1 Petang ditinjau dari segi proses?

4) Bagaimana efektivitas implementasi program praktik kerja industri di program studi keahlian agribisnis produksi tanaman SMK N 1 Petang ditinjau dari segi produk?

Secara umum, tujuan penelitian studi evaluasi terhadap efektivitas implementasi praktek kerja industri adalah untuk memberikan deskripsi atau gambaran tentang efektivitas implementasi program praktik kerja industri (prakerin) di program studi keahlian agribisnis produksi tanaman SMK N 1 Petang, dilihat dari aspek konteks, masukan, proses dan produk. Secara spesifik dan operasional, tujuan studi evaluasi ini adalah:

1) Untuk mendeskripsikan efektivitas implementasi program praktik kerja industri di program studi keahlian agribisnis produksi tanaman SMK N 1 Petang ditinjau dari segi konteks.

2) Untuk mendeskripsikan efektivitas implementasi program praktik kerja industri di program studi keahlian agribisnis produksi tanaman SMK N 1 Petang ditinjau dari segi masukan.

3) Untuk mendeskripsikan efektivitas implementasi program praktik kerja industri di program studi keahlian agribisnis produksi tanaman SMK N 1 Petang ditinjau dari segi proses.

4) Untuk mendeskripsikan efektivitas implementasi program praktik kerja industri di program studi keahlian agribisnis produksi tanaman SMK N 1 Petang ditinjau dari segi produk. 


\section{METODE PENELITIAN}

Pada bagian ini akan diuraikan beberapa hal, yaitu: 1) rancangan penelitian, 2) populasi dan sampel, 3) variabel penelitian, 4) metode pengumpulan data dan instrumen penelitian, 5) dan 6) metode analisis data.

Sesuai dengan model CIPP (context, Input, Process dan Product). Dalam penelitian ini, evaluasi hanya dilakukan pada variable context, Input, Process dan Product.

Evaluasi terhadap context berhubungan dengan ketersediaan landasan hukum, visi, misi, tujuan dan sasaran sekolah dan kurikulum. Evaluasi terhadap masukan (input) meliputi aspek permintaan masyarakat akan pendidikan, aspek siswa, dukungan dan partisipasi sekolah, aspek institusi/pasangan dan aspek pembiayaan. Evaluasi terhadap proses meliputi proses pengelolaan program, proses evaluasi, proses kerja sama dan partisipasi, dan proses berkelanjutan program. Sedangkan evaluasi terhadap produk meliputi kualitas lulusan yaitu seberapa besar peserta didik dapat dinyatakan kompeten pada bidang kejuruan yang ditempuhnya melalui proses uji kompetensi dan dapat diterima oleh dunia usaha dan dunia industri sesuai dengan bidang keahlian masing-masing.

Metode pengumpulan data yang digunakan dalam penelitian ini terdiri dari metode utama yang berupa angket/kuesioner dan metode pelengkap berupa metode wawancara dan metode dokumentasi. Metode kuesioner diberikan kepada seluruh guru dan siswa. Metode wawancara dan metode dokumentasi digunakan untuk memperkuat data-data yang diberikan oleh guru dan juga pelaku dalam DU/DI tempat siswa melakukan prakerin. Untuk memperoleh data yang diperlukan maka dalam penelitian ini digunakan beberapa metode. instrumen penelitian yang dibutuhkan dalam penelitian ini adalah kuesioner dan panduan wawancara. Kuesioner akan berperan sebagai pengumpul data sedangkan panduan wawancara berfungsi menunjang data utama apabila didapat data yang kurang jelas.

Teknik analisis data dalm penelitian ini yakni data yang telah diolah atau diproses kemudian dianalisis dengan skor-t. Skor-t merupakan angka skala yang menggunakan Mean dan Standar Deviasi (Koyan, 2004:44).

\section{HASIL DAN PEMBAHASAN}

Hasil pengolahan data penelitian dalam bentuk deskripsi/paparan data dan temuan penelitian tentang studi evaluasi tentang implementasi program praktik kerja industri (PRAKERIN) di program studi keahlian agribisnis produksi tanaman SMK N 1 Petang.

Deskripsi kuantitatif kriteria ideal teoretik dikonfirmasikan dengan skor yang diperoleh, disusun kategori efektifitas penerapan program praktik kerja industri (PRAKERIN) di program studi keahlian agribisnis produksi tanaman SMK N 1 Petang. dapat diketahui bahwa 2 dimensi dalam variabel konteks yaitu landasan hukum/peraturan, kebijakan yang mendasari program praktek kerja industri, dan dimensi visi, misi, tujuan, sasaran dan program sekolah tergolong sangat efektif. Sedangkan 1 dimensi yaitu kurikulum tergolong efektif. Skor ratarata untuk variabel konteks diperoleh sebesar 153,62 tergolong sangat efektif.

Dalam pengumpulan data variabel konteks peneliti menggunakan kuesioner, wawancara dan dokumentasi terhadap 38 responden yang terdiri dari: kepala sekolah, guru, pengguna dan siswa. Dalam variabel konteks ini terdapat 3 dimensi yang dinilai yaitu landasan hukum/peraturan, kebijakan yang mendasari program praktek kerja industri; visi, misi, tujuan, sasaran dan program sekolah; dan kurikulum. Ketiga dimensi ini diukur berdasarkan kuesioner yang terdiri dari 35 item. Skor maksimal variabel konteks adalah 190 sedangkan skor minimalnya adalah 38.

Deskripsi kuantitatif kriteria ideal teoretik dikonfirmasikan dengan skor yang diperoleh, disusun kategori efektifitas penerapan program praktik kerja industri (PRAKERIN) di program studi keahlian agribisnis produksi tanaman SMK N 1 Petang. Setelah deskripsi kuantitatif kriteria ideal teoretik dikonfirmasikan dengan skor yang diperoleh, dapat disusun kriteria efektifitas penerapan program praktik kerja industri pada komponen konteks. 
Dilihat variabel konteks yang terdiri dari 3 dimensi masing-masing memiliki rata-rata skor sebagai berikut. (1) Landasan hukum/peraturan, kebijakan yang mendasari program praktek kerja industri memiliki skor rata-rata 160,4 (34.80\%). (2) Visi, misi, tujuan, sasaran dan program sekolah memiliki skor rata-rata 157,75 (34,23\%). (3) Kurikulum memiliki skor rata-rata $142,71(30,97 \%)$.

Bila dicermati tampak diatas bahwa 2 indikator memiliki kategori sangat efektif dan 1 indikator memiliki kategori efektif. Akan tetapi, yang memberikan kontribusi efektifitas terbaik yaitu $34,80 \%$ terhadap variabel konteks adalah dimensi landasan hukum/peraturan, kebijakan yang mendasari program praktek kerja industri.

Dalam pengumpulan data variabel input peneliti menggunakan kuesioner, wawancara dan dokumentasi terhadap 38 responden yang terdiri dari: kepala sekolah, guru, dan pengguna. Dalam variabel input ini terdapat 4 dimensi yang dinilai yaitu permintaan masyarakat akan pendidikan, dukungan, dan partisipasi sekolah; siswa, institusi/pasangan (DU/DI); pembiayaan. Semua dimensi tersebut diukur berdasarkan kuesioner yang terdiri dari 32 item. Skor maksimal variabel input adalah 190 sedangkan skor minimalnya adalah 38.

Dapat diketahui bahwa 3 dimensi dalam variabel input yaitu permintaan masyarakat akan pendidikan, dukungan, dan partisipasi sekolah; siswa; dan pembiayaan tergolong sangat efektif. Sedangkan dimensi institusi/pasangan (DU/DI) tergolong efektif. Skor ratarata untuk variabel input diperoleh sebesar 152,05 tergolong sangat efektif.

Bila dicermati tampak diatas bahwa 3 dimensi memiliki kategori sangat efektif dan 1 dimensi tergolong efektif namun yang memberikan kontribusi efektifitas terbaik yaitu $26 \%$ terhadap variabel input adalah dimensi siswa.

Dalam pengumpulan data variabel proses peneliti menggunakan kuesioner, wawancara dan dokumentasi terhadap 89 responden yang terdiri dari: kepala sekolah, guru, pengguna dan siswa. Dalam variabel proses ini terdapat 4 dimensi yang dinilai yaitu proses pengelolaan program, proses keberlanjutan program, proses kerjasama dan partisipasi, dan proses evaluasi. Semua dimensi tersebut diukur berdasarkan kuesioner yang terdiri dari 31 item. Skor maksimal dalam variabel proses adalah 445 sedangkan skor minimalnya 89.

Dapat diketahui bahwa 4 dimensi dalam variabel proses yaitu proses pengelolaan program, proses keberlanjutan program, proses kerjasama dan partisipasi, dan proses evaluasi tergolong sangat efektif. Skor rata-rata untuk variabel proses diperoleh sebesar 389 tergolong sangat efektif.

Bila dicermati tampak diatas bahwa semua dimensi memiliki kategori sangat efektif namun yang memberikan kontribusi efektifitas terbaik yaitu $25,35 \%$ terhadap variabel proses adalah dimensi proses pengelolaan program.

Variabel proses yang terdiri dari 4 dimensi masing-masing memiliki rata-rata skor sebagai berikut. (1) Proses pengelolaan program memiliki skor rata-rata 394,5 (25,35\%). (2) Proses keberlanjutan program memiliki skor rata-rata 378,86 (24,35\%). (3) Proses kerjasama dan partisipasi memiliki skor rata-rata 390,63 (25,10\%). (4) Proses evaluasi memiliki skor rata-rata $392(25,19 \%)$.

Dalam pengumpulan data variabel produk peneliti menggunakan kuesioner terhadap 38 responden yang terdiri dari: kepala sekolah, wakil kepala sekolah dan guru. Dalam variabel produk ini terdapat 2 dimensi yang dinilai yaitu output dan outcome. Semua dimensi tersebut diukur berdasarkan kuesioner yang terdiri dari 44 item. Skor maksimal variabel produk adalah 190 sedangkan skor minimalnya adalah 38.

Dapat diketahui bahwa dimensi output dalam variabel produk tergolong sangat efektif sedangkan dimensi outcome tergolong efektif. Skor rata-rata untuk variabel proses diperoleh sebesar 159,94 tergolong sangat efektif.

Variabel produk yang terdiri dari 2 dimensi masing-masing memiliki rata-rata skor sebagai berikut. (1) Output memiliki skor rata-rata 169,7 (53,05\%). (2) Outcome memiliki skor rata-rata 150,18 (46,95\%).

Selain menggunakan perhitungan kriteria ideal teoretik (Criterium Ideal Teoretical Reference), analisis data juga didasarkan pada penggunaan skor baku Z (Z-score) untuk Jurnal Administrasi Pendidikan Indonesia $\mid 70$ 
menentukan nilai $\mathrm{T}$ dari masing-masing komponen yang dilakukan secara manual dengan bantuan program aplikasi komputer Microsoft Excel. Pertama-tama pelaksanaan perhitungan dilakukan dengan cara mengubah skor mentah menjadi nilai $T$ dengan rumus: $T$ $=10 Z+50$. Dimana Z-Score adalah angka yang menunjukkan perbandingan perbedaan skor tiap dimensi dari Mean, dengan Standar Deviasi-nya, yang selanjutnya nilai T setiap variabel dikonsultasikan dengan kriteria untuk menentukan apakah nilai T dari setiap variabel yang dihitung tergolong dalam kategori positif (+) atau negatif (-).

Berikut ini akan disajikan hasil analisis efektifitas penerapan PRAKERIN dengan menggunakan skor $Z$ dan nilai T per variabel, yang dianalisis berdasarkan kelompok dimensi untuk masing-masing variabel pada SMKN 1 Petang yang menjadi obyek penelitian yaitu sebagai berikut.

Berdasarkan analisis terdapat 2 dimensi yang memiliki arah positif yaitu dimensi landasan hukum/peraturan, kebijakan yang mendasari program praktek kerja industri dan visi, misi, tujuan, sasaran dan program sekolah. Sedangkan dimensi yang memiliki arah negatif sebanyak 1 dimensi yaitu kurikulum. Berdasarkan hal tersebut, dimensi yang memiliki arah positif lebih banyak dibandingkan dengan arah negatif. Sehingga variabel konteks memiliki arah positif. Selain itu, variabel konteks memiliki rata-rata T skor sebesar 50,00 yang tergolong positif.

Berdasarkan data analisis, untuk variabel input skor rata-rata diperoleh sebesar 152,05. Terdapat 3 dimensi yang memiliki arah positif yaitu dimensi permintaan masyarakat akan pendidikan, dukungan, dan partisipasi sekolah; siswa; dan pembiayaan. Sedangkan dimensi yang memiliki arah negatif sebanyak 1 dimensi yaitu institusi/pasangan (DU/DI). Berdasarkan hal tersebut, dimensi yang memiliki arah positif lebih banyak dibandingkan dengan arah negatif. Sehingga variabel input memiliki arah positif. Hal ini juga dapat dilihat dari rata-rata $T$ skor variabel input adalah 50,00 tergolong positif.

Berdasarkan data analisis, untuk variabel proses skor rata-rata diperoleh sebesar 389. Terdapat 3 dimensi yang memiliki arah positif yaitu dimensi proses pengelolaan program, proses kerjasama dan partisipasi, dan proses evaluasi. Sedangkan dimensi yang memiliki arah negatif sebanyak 1 dimensi yaitu proses keberlanjutan program. Berdasarkan hal tersebut, dimensi yang memiliki arah positif lebih banyak dibandingkan dengan arah negatif. Sehingga variabel proses memiliki arah positif. Hal ini juga dapat dilihat dari rata-rata T skor variabel input adalah 50,00 tergolong positif.

Berdasarkan data analisis, untuk variabel produk skor rata-rata diperoleh sebesar 159,94 . Satu dimensi memiliki arah positif yaitu dimensi output dan satu dimensi memiliki arah negatif yaitu dimensi outcome. Secara keseluruhan rata-rata $T$ skor variabel produk adalah 50,00 tergolong positif.

Berdasarkan analisis, nampak variabel konteks, $\Sigma(+)>\Sigma(-)$ dengan rata-rata T skor sebesar $50,00 \geq 50$ sehingga hasilnya positif, variabel Input $\Sigma(+)>\Sigma(-)$ dengan rata-rata T skor sebesar $50,00 \geq 50$ sehingga hasilnya positif, variabel proses $\Sigma(+)>\Sigma(-)$ dengan ratarata $\mathrm{T}$ skor sebesar $50,00 \geq 50$ sehingga hasilnya positif, dan variabel produk $\Sigma(+)=\Sigma(-)$ dengan rata-rata $T$ skor sebesar $50,00 \geq 50$ sehingga hasilnya positif. Jadi secara keseluruhan menghasilkan pola positif - positif - positif - positif $(++++)$. Untuk menentukan tingkat efektivitas pelaksanaan PRAKERIN, data hasil pengukuran masing-masing varibel konteks, input, proses dan produk diverifikasi ke dalam kuadran Glickman.

Hasil diverifikasi data Hasil pengukuran masing variabel seperti ditunjukkan pada Gambar 4.6 posisi nilai CIPP dengan pola ++++ berada pada kuadran I. Posisi ini menunjukkan bahwa kondisi penerapan PRAKERIN SMK Negeri 1 Petang terkategori efektif. Jadi dapat disimpulkan bahwa penerapan PRAKERIN SMK Negeri 1 Petang terkate bagian ini akan dibahas hasil penelitian yang telah dipaparkan sebelumnya. Hal ini bertujuan agar mendapat jawaban yang lebih tajam tentang efektivitas penerapan PRAKERIN di di program studi keahlian agribisnis produksi tanaman SMK Negeri 1 Petang. Pembahasan dibagi menjadi empat, yaitu: konteks (latar), input (masukan), proses dan produk. 
Berdasarkan hasil analisis yang dilakukan didapat bahwa pada variabel konteks, ada dua dimensi yang terkategori sangat efektif (Landasan hukum/peraturan, kebijakan yang mendasari program praktek kerja industri dan Visi, misi, tujuan, sasaran dan program sekolah) dan satu kategori terkategori efektif (kurikulum). Selanjutnya, berdasarkan analisis dengan skor T ditemukan bahwa dimensi yang terkategori sangat efektif memiliki arah yang positif. Sementara dimensi yang terkategori efektif memiliki arah yang negatif. Hal ini menunjukan bahwa masih ada masalah yang dialami pada bagian kurikulum sehingga perlu dilakukan langkah-langkah perbaikan.

Selain itu, tujuan, sasaran dan program sekolah yang telah diterapkan di SMK N 1 Petang juga efektif. Hal ini menunjukan bahwa pemahaman sekolah tentang hakekat bidang keahlian yang dikembangkan. Berdasarkan Dikmenjur (2008) yang menyatakan prakerin dilaksanakan dengan pola penyelenggaraan diklat yang dikelola bersama-sama antara SMK dengan industri/asosiasi profesi sebagai institusi pasangan (IP), mulai dari tahap perencanaan, pelaksanaan hingga evaluasi dan sertifikasi yang merupakan satu kesatuan program dengan menggunakan berbagai bentuk alternatif pelaksanaan. Hal ini berarti, halhal yang telah ditetapkan oleh Dikmenjur (2008) telah diterapkan dengan baik oleh SMK N 1 Petang. Selain hal-hal yang sudah efektif, ternyata masih ada hal yang belum efektif dan bergerak ke arah yang negatif.

Permasalahan lain yang muncul adalah ketersediaan sarana penunjang untuk melatih skill siswa. Memang harus diakui bahwa selama ini sarana belum lengkap dan kurang mengikuti jaman. Sebagai dampaknya, pada saat prakerin, banyak siswa yang kurang paham fungsi dan cara mengoperasikan alat-alat di tempat praktek. Inilah yang membuat DU/DI sering menilai sekolah kurang matang mempersiapkan siswa untuk praktek di lapangan. Terakhir, kurangnya relevansi yang yang dilakukan oleh DU/DI menjadi masalah. Hal ini memang karena pihak sekolah belum optimal mensosialisasikan kriteria yang digunakan oleh sekolah. Selama ini, pihak DU/DI menilai kompeteni siswa menggunakan instrumen yang sama dalam menilai para karyawannya. Hal ini tentunya kurang pas dengan yang dibuat oleh pihak sekolah.

Hasil analisis menunjukan bahwa ada tiga dimensi yang terkategori sangat efektif (a. permintaan masyarakat akan pendidikan, dukungan, dan partisipasi sekolah, b. siswa dan c. pembiayaan) dan satu dimensi terkategori efektif (Institusi/pasangan DU/DI). Selanjutnya, berdasarkan analisis dengan skor T didapat bahwa dimensi yang terkategori sangat efektif memiliki arah positif dan yang efektif memiliki arah negatif. Di sini variabel permintaan masyarakat akan pendidikan, dukungan, dan partisipasi sekolah memiliki nilai terendah dari yang lain atau juga hampir menuju arah yang negatif. Hal ini berarti dimensi ini hampir terkategori negatif.

Hasil ini menunjukan bahwa daya dukung untuk pelaksanaan prakerin sudah sangat baik. Secara spesifik, masyarakat telah memiliki pemahaman yang baik tentang pola pendidikan di sekolah menengah kejuruan. Selain itu, mereka juga berharap anaknya bisa lebih maju dari mereka. Di bidang keahlian ini, kebanyakan siswanya adalah anak petani. Jadi, mereka menaruh harapan yang sangat besar pada sekolah ini untuk membuat anaknya menjadi sukses di masa depan. Selain itu, dukungan dari pihak dinas kabupaten dan provinsi terhadap bidang keahlian ini tinggi. Pihak dinas biasanya ikut memberikan masukan terhadap pengembangan SMK.

yang perlu mendapat perhatian adalah keefektifan pelaksanaan uji kompetensi di DU/DI. Selama ini, keefektifanya masih belum sesuai dengan harapan sekolah. Untuk itu, pihak sekolah harus mensosialisasikan pelaksanaan uji kompetensi kepada pihak DU/DI dengan baik. Selama ini, pihak DU/DI masih menggunakan penilaian intern perusahaan untuk menilai kompetensi siswa. Hal ini tentu akan berbeda dari DU/DI yang satu dengan yang lain.

Hasil analisis menunjukan bahwa keempat dimensi terkategori sangat efektif (a. proses pengelolaan program, b. proses berkelanjutan program, c. proses kerja sama dan partisipasi dan d. proses evaluasi). Namun, setelah data dirubah ke skor T, dimensi "proses 
keberlanjutan program" memiliki arah negatif. Hal ini berarti bahwa masih ada permasalahan yang ditemui pada dimensi ini.

Hasil ini menunjukan bahwa pelaksanaan prakerin di Program Studi Keahlian Agribisnis Produksi Tanaman SMK N 1 Petang berjalan bagus atau efektif. Dalam menjalankan prakerin, proses pengelolaan program memegang peranan yang sangat penting. Dengan penyusunan program yang baik maka pengelolaan prakerin juga menjadi baik. Dalam pengelolaan program, pihak sekolah telah melakukan koordinasi dengan para guru, pemerintah dan beberapa DU/DI. Akan tetapi, kerja sama dengan pihak DU/DI belum mampu banyak dilakukan mengingat sekolah ini masih baru dan pihak sekolah masih mencari-cari bentuk kerjasama.

Dalam mengembangkan program lanjutan, sekolah sudah melakukan beberapa pendekatan dengan pihak DU/DI. Namun sampai saat ini, hanya ada beberapa DU/DI yang telah menjalin kerjasama yang resmi. Ke depannya diprediksi akan terus bertambah karena beberapa DU/DI telah memberi sinyal positif. Dengan semakin banyaknya DU/DI yang terlibat, sekolah akan mampu menyusun program lanjutan yang tentunya berguna bagi kedua belah pihak. Program lanjutan sifatnya tidak hanya pada satu hal saja, tetapi juga bervariasi. Akan tetapi, fokus utama adalah pengembangan kompetensi siswa yang sesuai dengan kebutuhan jaman. Hal ini mengingat kebutuhan yang selalu dinamis sehingga pihak sekolah pun juga harus dinamis dan mengikuti kebutuhan DU/DI.

Berdasarkan analisis data yang dilakukan diketahui bahwa dimensi output terkategori sangat efektif dan outcome terkategori efektif. Setelah data ditransformasikan ke skor T, diketahui bahwa output bergerak ke arah positif dan outcome ke arah negatif. Hal ini berarti masih ada beberapa hal yang perlu dibenahi pada dimensi outcome.

Hasil ini menunjukan bahwa output sekolah terkategori efektif atau bagus. Pada bagian ini, pihak sekolah telah benar-benar mempersiapkan peserta didik untuk terjun ke lapangan. Berbagai hal pun telah dilakukan baik berhubungan dengan akademisnya maupun non akademisnya. Hal ini dilakukan agar mereka tidak mengalami masalah dalam pelaksanaan prakerin di lapangan. Selain itu, para guru produktif juga telah berkomitmen untuk melakukan yang terbaik yang mampu menunjang keberhasilan siswa selama prakerin. Sebelum prakerin dilakukan, pihak sekolah juga telah menanyakan kesiapan pihak DU/DI. Selama ini pihak DU/DI selalu siap menerima siswa SMK.

Ada tiga output yang didapat setelah siswa melakukan prakerin. Pertama, kompetensi siswa jauh meningkat setelah prakerin dilaksanakan. Hal ini bisa terlihat dari hasil uji kompetensi yang diajarkan sebelum prakerin dan sesudah prakerin dilaksanakan. Kedua, prosentase siswa yang melanjutkan ke jenjang perguruan tinggi juga semakin meningkat. Hal ini mereka putuskan setelah selesai prakerin. Selama prakerin, pihak DU/DI rupanya telah memberi masukan kepada siswa tentang peluang yang lebih besar jika melanjutkan ke jenjang yang lebih tinggi jika mengambil bidang keahlian yang sama. Ketiga, prosentase nilai kelulusan siswa juga meningkat.

\section{IMPLIKASI PENELITIAN}

Berdasarkan hasil penelitian ini, ada dua implikasi yang hendak disampaikan. Secara umum pelaksanaan prakerin sudah efektif. Hal ini berimplikasi pada proses pembelajaran dan kurikulum yang sudah tepat sasaran. Selain itu, pelaksanaan prakerin juga sudah berjalan sesuai dengan program sekolah yang telah ditetapkan. Hal seperti ini hendaknya terus dipertahankandan bila perlu ditingkatkan agar ke depannya Prakerin akan semakin baik dan mampu menjadi wadah bagi siswa untuk berlatih mengembangkan keterampilannya.

Implikasi yang kedua adalah perlunya perbaikan dalam hubungannya dengan DU/DI. Sebagai pengguna lulusan, keterlibatan mereka masih kurang baik dalam penyusunan kurikulum, kerja sama untuk lulusan serta program jangka panjang. Jika hal ini tidak ditindaklanjuti atau diperbaiki maka SMK hanya akan mencetak siswa yang tidak sesuai dengan kebutuhan pasar. Ini akan berdampak pada alumni SMK yang akan menjadi 
pengangguran. Padahal, sebenarnya SMK dibuat untuk memberikan siswa keterampilan siap kerja.

\section{PENUTUP}

Dalam Undang-undang Sistem Pendidikan Nasional (UUSPN) No. 20 tahun 2003 pasal 15 menyatakan bahwa pendidikan kejuruan adalah pendidikan menengah yang mempersiapkan peserta didik terutama untuk bekerja dalam bidang tertentu. Jadi pendirian SMK ditujukan agar semua anak yang masuk SMK dapat bekerja sesuai bidang keahlian yang ditekuni sesuai program keahlian ataupun membuka lapangan pekerjaan sendiri sesuai bidang yang telah di pelajari.

Tujuan pendidikan menengah kejuruan menurut Undang-Undang Nomor 20 Tahun 2003, terbagi menjadi tujuan umum dan tujuan khusus. Tujuan umum pendidikan menengah kejuruan adalah : (a) meningkatkan keimanan dan ketakwaan peserta didik kepada Tuhan Yang Maha Esa; (b) mengembangkan potensi peserta didik agar menjadi warga Negara yang berakhlak mulia, sehat, berilmu, cakap, kreatif, mandiri, demokratis dan bertanggung jawab; (c) mengembangkan potensi peserta didik agar memilikiwawasan kebangsaan, memahami dan menghargai keanekaragaman budaya bangsa Indonesia; dan (d) mengembangkan potensi peserta didik agar memiliki kepedulian terhadap lingkungan hidup dengan secara aktif turut memelihara dan melestarikan lingkungan hidup, serta memanfaatkan sumber daya alam dengan efektif dan efisien.

Tujuan khusus pendidikan menengah kejuruan adalah sebagai berikut: (a) menyiapkan peserta didik agar menjadi manusia produktif, mampu bekerja mandiri, mengisi lowongan pekerjaan yang ada sebagai tenaga kerja tingkat menengah sesuai dengan kompetensi dalam program keahlian yang dipilihnya; (b) menyiapkan peserta didik agar mampu memilih karir, ulet dan gigih dalam berkompetensi, beradaptasi di lingkungan kerja dan mengembangkan sikap profesional dalam bidang keahlian yang diminatinya; (c) membekali peserta didik dengan ilmu pengetahuan, teknologi dan seni agar mampu mengembangkan diri di kemudian hari baik secara mandiri maupun melalui jenjang pendidikan yang lebih tinggi; dan (d) membekali peserta didik dengan kompetensikompetensi yang sesuai dengan program keahlian yang dipilih.

Sekolah SMK dianggap layak untuk dikembangkan di Indonesia mengingat jumlah penduduk yang sangat besar. Terlebih banyaknya pula jumlah pengangguran di Indonesia. Selain itu biaya pendidikan yang tergolong tinggi untuk bisa melanjutkan ke perguruan tinggi. Oleh karena itu, mengembangkan SMK atau yang saat ini sering disebut Pendidikan Sistem Ganda dianggap sebagai langkah jitu pemerintah dalam mengurangi pengangguran serta sebagai usaha mempersiapkan tenaga kerja yang produktif untuk dunia usaha (DU) dan industri (DI).

Ada tiga langkah inovatif dan revolusioner yang dilakukan pemerintah untuk menaikkan citra pamor SMK di masyarakat. Pertama dengan menambah jumlah SMK dan mengurangi jumlah SMA. Sehingga rasio SMK dan SMK pada tahun ini diharapkan mencapai 30:70. Kedua, diselenggarakannya Lomba Kompetensi Siswa (LKS) baik tingkat kabupaten, provinsi dan nasional. Bahkan, pada LKS dipamerkan pula hasil kreasi anak SMK. Hal ini sebagai wadah anak SMK untuk terus berpacu meningkatkan kompetensinya pada bisang SMK yang mereka geluti. Ketiga adalah iklan di televisi. Mungkin sudah tidak asing mendengar slogan "SMK Bisa!". Yang mana diperankan oleh artis yang sangat sukses dan saat ini menjadi salah satu anggota DPR RI dan mengaku sebagai tamatan SMK. Tentu saja langkah ini diharapkan mampu memicu anak SMK terus maju dan tidak kalah saing dengan anak SMA.

Sebagai imbas dari pengembangan SMK oleh pemerintah maka pada 26 April 2006 didirikanlah SMK N 1 Petang dengan bidang keahlian "Agribisnis dan Agroteknologi". Sekolah ini terletak di tempat yang sangat representatif yaitu di Desa Pelaga, Kecamatan Petang, Kabupaten Badung. Daerah ini adalah sentra pertanian di Kabupaten Badung dengan keadaan georgrafis yang sangat mendukung didirikannya SMK agribisnis dan 
agroteknologi. Terdapat dua program studi keahlian, Agribisnis Produksi Tanaman dan Agribisnis Hasil Pertanian.

Sebagai sekolah menengah kejuruan, SMK ini pun menerapkan Pendidikan Sistem Ganda dengan tujuan mendekatkan siswa dengan DU/DI. Yang muaranya sebagai wadah siswa untuk mengembangkan kompetensi keahliannya. DU/DI akan memberikan gambaran tentang keahlian apa yang harus mereka miliki dan kuasai agar mereka siap diterima di dunia kerja. Wujud kerjasama SMK dan DU/DI sangat jelas pada pelaksanaan Program Praktek Kerja Industri (Prakerin). Pelaksanaan Prakerin sesuai dengan Kepmendikbud No. 080/V/1993 tentang kurikulum sekolah menengah kejuruan yang menyatakan :

a. Menggunakan unit produksi sekolah beroperasi secara professional sebagai wahana pelatihan kejuruan.

b. Melaksanakan sebagai kelompok mata pelajaran kejuruan di sekolah, dan sebagai lainnya di dunia usaha dan industri.

c. Melaksanakan kelompok mata pelajaran keahlian kejuruan sepenuhnya di masyarakat dunia usaha dan industri.

Program Praktik Kerja Industri merupakan suatu tahap persiapan profesional dimana seorang siswa yang hampir menyelesaikan studi secara formal bekerja dilapangan dengan supervisi seorang administrator yang kompeten dalam jangka waktu tertentu, yang bertujuan untuk mengembangkan kemampuan melaksanakan tanggung jawab dalam bidangnya (Hamalik, 2001:91). Pelaksanaan Praktik Kerja Industri secara tidak langsung akan memberikan pengetahuan dan pengalaman dalam bekerja. Pengalaman yang diperoleh pada saat melaksanakan praktik industri, selain mempelajari bagaimana cara mendapatkan pekerjaan, juga belajar bagaimana memiliki pekerjaan yang relevan dengan bakat dan minat yang dimiliki oleh siswa tersebut.

Lebih lanjut dalam Undang-Undang Prakerin Dikmendikti, (2003) diungkapkan bahwa Praktek Kerja Industri (Prakerin) adalah program wajib yang harus diselenggarakan oleh sekolah khususnya sekolah menengah kejuruan dan pendidikan luar sekolah serta wajib diikuti oleh siswa/warga belajar. Penyelenggaraan Praktek Kerja Industri akan membantu peserta didik untuk memantapkan hasil belajar yang diperoleh di sekolah serta membekali siswa dengan pengalaman nyata sesuai dengan program studi yang dipilihnya.

Program Prakerin yang dilaksanakan di industri/perusahaan, menurut Dikmenjur (2008) adalah meliputi:

1. Praktik dasar kejuruan, dapat dilaksanakan sebagian di sekolah, dan sebagian lainnya di industri, apabila industri memiliki fasilitas pelatihan di industrinya. Apabila industri tidak memiliki fasilitas pelatihan, maka kegiatan praktik dasar kejuruan sepenuhnya dilakukan di sekolah

2. Praktik keahlian produktif, dilaksanakan di industri dalam bentuk "on job training", berbentuk kegiatan mengerjakan pekerjaan produksi atau jasa (pekerjaan sesungguhnya) di industri/perusahaan sesuai program keahliannya.

3. Pengaturan program 1), dan 2) harus disepakati pada awal program oleh kedua pihak.

Mengingat pentingnya peran Prakerin dalam pengembangan kompetensi siswa, SMK N 1 Petang pun melakukan berbagai upaya untuk pelaksanaan Prakerin. Kerja sama dengan berbagai DU/DI yang mendukung pun dilakukan agar siswa benar-benar mendapatkan tempat yang mampu memberikan pengalaman yang bermakna dalam dalam pengembangan kompetensinya. Selain itu, pembekalan-pembekalan pun diberikan agar siswa mendapat gambaran tentang apa yang akan mereka hadapi saat Prakerin dan apa saja tugastugasnya.

Mengingat usia SMK N 1 Petang yang masih relatif muda (kurang dari 10 tahun) maka dirasakan sangat perlu untuk melakukan evaluasi terhadap pelaksanaan prakerin di sekolah ini. Dengan melakukan evaluasi maka gambaran umum dan detail tentang pelaksanaan Prakerin dapat diketahui oleh guru,sehingga akan menjadi masukan bagi sekolah untuk terus meningkatkan kualitas prakerin. Evaluasi akan mencakup empat komponen, yaitu: 
konteks (context), masukan (input), proses (process) dan produk (product). Dalam penelitian ini, model evaluasi CIPP (context, input, process dan product).

Data dalam penelitian ini dikumpulkan dengan kuesioner. Sebelum digunakan, kuesioner terlebih dahulu divalidasi dengan menguji validitas isinya. Validitas butir dan reliabilitas tidak dilakukan karena kuesioner udah pernah divalidasi sebelumnya. Hasil penilaian dari kedua judges menunjukan bahwa semua butir telah valid dari segi isi.

Selanjutnya data di kumpulkan. Responden mencakup warga sekolah seperti kepala sekolah, ketua program keahlian, guru dan siswa. Data yang diperolah kemudian dianalisis secara statistik. Data yang telah diolah atau diproses kemudian dianalisis dengan skor-t. Selanjutnya menentukan arah t-skor dan menentukan arah (+), ( - ) ke kuadran Glickman.

Hasil analisis menunjukan bahwa implementasi program praktik kerja industri di program studi keahlian agribisnis produksi tanaman SMK Negeri 1 petang ditinjau dari segi konteks, masukan, proses dan produk adalah efektif. Meskipun demikian, masih ada beberapa hal yang yang perlu mendapat perhatian dan perlu ditingkatkan.

\section{DAFTAR RUJUKAN}

Ahmadi, H Abu. 2004. Sosiologi Pendidikan. Jakarta. Rineka Cipta.

Budiningsih, C Asri. 2005. Belajar dan Pembelajaran. Jakarta. Rineka Cipta.

Chan, Sam M. (2005). Kebijakan Pendidikan Era Otonomi Daerah. Jakarta: Grafindo

Danim, Sudarwan. 2003. Menjadi Komunitas Pembelajar. Jakarta. Bumi Aksara.

Darmada, I Made. 2001. Kompetensi Kejuruan Lulusan Sekolah Menengah Kejuruan di Denpasar dan sekitarnya. Tesis. Universitas Negeri Yogyakarta

Gunawan, Ary H. 2000. Sosiologi Pendidikan. Jakarta: Rineka Cipta.

Gerungan. W. A. 2004. Psikologi Sosial. Bandung: Refika Aditama.

Hadiyanto .(2004). Mencari Sosok Desentralisasi Manajemen Pendidikan di Indonesia. Jakarta : Rineka Cipta

Hendrawati, Andriani. 2014. Kontribusi Sarana Prasarana Belajar, Bimbingan Karier Kejuruan, Dan Praktek Kerja Industri Terhadap Kompetensi Kejuruan Lulusan SMK Se-Kecamatan Karangasem. Tesis (Tidak diterbitkan ). Singaraja. Program Pasca Sarjana Universitas Pendidikan Ganesha. 